\title{
Interpretation of Agricultural Pest Problem Handling System in Usada Wisada Pari Scripture
}

\author{
Putu Sabda Jayendra ${ }^{*}$, Kadek Ayu Ekasani ${ }^{2}$, Ida Bagus Subrahmaniam Saitya ${ }^{3}$, Made Wahyu \\ Mahendra $^{4}$ \\ Institut Pariwisata dan Bisnis Internasional, Indonesia; sabda@stpbi.ac.id \\ 2 Institut Pariwisata dan Bisnis Internasional, Indonesia; ekasani@stpbi.ac.id \\ 3 Universitas Hindu I Gusti Bagus Sugriwa Denpasar, Indonesia; tugusbramsaitya@uhnsugriwa.ac.id \\ 4 Universitas Hindu I Gusti Bagus Sugriwa Denpasar, Indonesia; madewahyumahendra@uhnsugriwa.ac.id \\ * Correspondence: sabda@stpbi.ac.id
}

Received: 2021-02-12; Accepted: 2021-06-02; Published: 2021-08-31

\begin{abstract}
The knowledge of cultivation and the methods of treating and solving pest problems naturally without neglecting the local culture has been an inseparable aspect of Balinese agricultural life, which is known for its irrigation system called subak. This study aims to examine agricultural scripture named Usada Wisada Pari from two perspectives. First, this study examines the types of pests and its countermeasure. Secondly, it is important to study the lexicon form of these pests. This study shows that the types of rice pests in the Usada Wisada Pari text are categorized into two types, namely animals and plants. The countermeasure consists of natural ritual elements from plants and incantations. Furthermore, this research also shows that all kinds of plague and agricultural pests, along with ways to overcome them, reflect the very strong Shivaistic teachings. All kinds of diseases, countermeasures and prevention are described as the authority of Lord Shiva as the god of destruction in the Hindu concept. It can be concluded that the scripture of Usada Wisada Pari is a text that provides knowledge about rice pest antidotes in an environmentally friendly and holistic manner because it involves natural and religious elements. This study is expected to contribute both to academics or future researchers as well as to the public. It is hoped that academics and researchers can use this present study as a source and expand as well as deepen the object of study based on ethnoagriculture. Meanwhile, the general public can increase their knowledge regarding alternative management of agricultural epidemics in synergy with nature and local wisdom.
\end{abstract}

Keywords: Agriculture; ethnolinguistics; lexicon.

Abstrak: Pengetahuan bercocok tanam dan cara-cara menangani dan mengatasi masalah hama secara
alami tanpa mengabaikan budaya setempat telah menjadi bagian tak terpisahkan dari kehidupan
pertanian Bali yang dikenal dengan sistem pengairannya yang disebut subak. Penelitian ini bertujuan
untuk mengkaji kitab suci pertanian bernama Usada Wisada Pari dari dua perspektif. Pertama,
penelitian ini mengkaji jenis-jenis hama dan penanggulangannya. Kedua, penting untuk mempelajari
bentuk leksikon dari hama ini. Penelitian ini menunjukkan bahwa jenis hama padi dalam teks Usada
Wisada Pari dikategorikan menjadi dua jenis, yaitu hewan dan tumbuhan. Penanggulangannya terdiri
dari unsur-unsur ritual alami dari tumbuhan dan mantra. Selain itu, penelitian ini juga menunjukkan
bahwa segala macam wabah dan hama pertanian, beserta cara penanggulangannya mencerminkan
ajaran Shiva yang sangat kuat. Segala macam penyakit, penanggulangan dan pencegahan
digambarkan sebagai otoritas Dewa Siwa sebagai dewa pemusnah dalam konsep Hindu. Dapat
disimpulkan bahwa Kitab Usada Wisada Pari merupakan teks yang memberikan pengetahuan tentang
penangkal hama padi secara ramah lingkungan dan holistik karena melibatkan unsur alam dan
agama. Penelitian ini diharapkan dapat memberikan kontribusi baik bagi akademisi atau peneliti
selanjutnya maupun kepada masyarakat luas. Diharapkan para akademisi dan peneliti dapat
menggunakan penelitian ini sebagai sumber dan memperluas serta memperdalam objek kajian 
berbasis etnoagrikultur. Sementara itu, masyarakat umum dapat menambah pengetahuan tentang alternatif penanggulangan wabah pertanian yang bersinergi dengan alam dan kearifan lokal.

Kata Kunci: Etnolinguistik; leksikon; pertanian.

\section{Introduction}

The agricultural sector in Bali plays an important role in community empowerment, especially in rural areas. This is proven by the fact that UNESCO at the 36th session on June 29, 2012, at St. Petersburg, Russia has designated Subak as a world cultural heritage which is a Balinese agricultural water management system called the Cultural Landscape of Bali Province: The Subak System as a Manifestation of the Tri Hita Karana Philosophy (Sartini, 2017).

This sector is empowered by the Balinese philosophy of Sekala (visible realm) and Niskala (spiritual realm) (Ardana, 2012). The Sekala aspect is usually manifested by concrete actions, while the Niskala aspect is manifested in ritual. Likewise, in relation to the agricultural aspect, Balinese people do have not only knowledge of the farming system, but also the ritual system that accompanies the journey of plant growth. This is reflected by the scripture and ancient texts that describe in detail regarding agricultural aspect.

The scripture of Usada Wisada Pari is one of the ancient texts that describe agriculture, especially in handling epidemics or pests. This text is written in ancient Javanese language, which in order to be deciphered, it needs to be examined for its synonymous meaning in Balinese or Indonesian language. This text is considered unique compared to other scriptures. Generally, Balinese people would refer to other scripture such as Dharman Pamacul which tells how to worship the Bhatari Sri as the Goddess of Prosperity (Artayasa, 2017). Another example is stated by Ardiyasa, (2020) in his study entitled "Spiritual Mitigation in the Manuscript of Roga Sanghara Bumi". This manuscript contains the causes of disasters and epidemics that occur in the world as well as its characteristics. Thus, this manuscript also states that the worship of Bhatari Sri can help people to prevent and solve this problem (Diari, 2020; Jayendra, 2021). In addition, Balinese people sees the agricultural aspect as a feminist aspect which makes worshipping Batari Sri is imminent (Diari, 2020).

The scripture of Usada Wisada Pari is considered unique compared to the previous studies. This scripture worships the existence of Ida Sang Hyang Siwa Gni as the god of destruction, which is seen from a masculine aspect. Therefore, understanding the content and meaning of the scripture will help us enrich the repertoire of socio-cultural knowledge of the Balinese Hindu community, and the knowledge in it can complement each other with the contents of other texts. This is important since many of the latest generations has not yet been familiar with the existence of this knowledge. Ogburn (1950) argues that this ignorance to past knowledge can lead to socio-cultural changes since material culture is accepted more quickly than non-material culture. This is one of the reasons why people nowadays tend to shift to practical ways in agriculture, which actually harm the land. For instance, pesticides that should be used to eradicate pests actually impact environmental pollution, be it water, air or soil, and have an impact on human health (Yuantari, 2011).

Therefore, it is necessary to state this study is important to be conducted to have further understanding of the content and meaning of scripture of Usada Wisada Pari. This study is expected to contribute to preserving the ancestral values and can be implemented in a sustainable manner.

This study employs a mixed design between literature and field studies. The literature study was carried out on the scripture of Usada Wisada Pari, while the field study was carried out by observation and interview methods. The observed aspects cover; (1) knowledge of the specifications of pests that attack agricultural crops (between text and context in the field), (2) knowledge of terms or lexicons in the classification of cure and medicine, (3) common pest management patterns by farmers compared to the text in the scripture. The interview was conducted to four respondents. Further, the data will be analyzed by using interpretive data analysis techniques. The result of the analysis is presented descriptively qualitatively. 


\section{Identification of Lexicons in the Scripture of Usada Wisada Pari}

Usada Wisada Pari contains a detailed classification of words in Old Javanese, which describe the types of pests, the means of deterrence, and the spells used. This sub-section specifically classifies the types of pests and means of preventing the plague, while the incantations will be described in the next sub-section dealing with the technical management of agricultural outbreaks. The identification of lexicons in the Usada Wisada Pari can be detailed as follows:

Identification of Mrana

Table 1 The Lexicon of Mrana Classification

\begin{tabular}{llll}
\hline No & $\begin{array}{c}\text { Kawi (Ancient } \\
\text { Javanese) }\end{array}$ & \multicolumn{1}{c}{ Indonesian Language } & English \\
\hline 1 & Balang Sangit & Walang Sangit & Stinkers \\
\hline 2 & Bikul & Tikus & Rats \\
\hline 3 & Bojog & Kera & Monkeys \\
\hline 4 & Gowak & Gagak & Crows \\
\hline 5 & Jukutan & Gulma & Weeds \\
\hline 6 & Kdis & Burung & Birds \\
\hline 7 & Lanas & Busuk batang & Rotten Stem \\
\hline 8 & Mati Busung & Penggerek batang & Stem Borers \\
\hline
\end{tabular}

From the table 1, it can be seen that animals mainly cause the outbreaks. For Kdis (no. 6), which means birds, the text does not mention what types of birds are often becoming the cause of outbreak. However, aside from crows which are mentioned on the table, sparrows also become the most frequently caused of outbreak where in Bali it is called kdis perit by locals.

Jukutan is a plant that is classified as a rice weed. The species is not specifically mentioned in the Usada Wisada Pari text, thus it refers to a common wild pest. According to Rukmana and Saputra (1999), weeds have several meanings such as plants that are not in place, plants that have a negative value, or any plants that grow in places that are not wanted, especially where humans intend to cultivate farming plants. In this case, weeds found in rice fields are plants other than rice in the field area and are considered disturbing because they tend to consume nutrients in the soil which are actually intended for rice only. In relation to that point, Ladja, Hidayat, \& Dramaga (2016) specify the weeds that often interfere with rice growth in paddy fields. The details are presented in the following table.

Table 2 Weeds Classification

\begin{tabular}{llll}
\hline No & Weeds classification & Latin & English \\
\hline 1 & Adas-adasan & Fimbristilys miliacea & Fimbry \\
\hline 2 & Dekeng & Cyperus iria & rice flatsedge \\
\hline 3 & Eceng Padi & Monochoria vaginalis & pickerel weed \\
\hline 4 & Rubah Sila & Ludwigia adscendens & water primrose \\
\hline 5 & Gonda & Sphenoclea zeylanica & gooseweed \\
\hline 6 & Genjer & Limnocharis flava & yellow bur head \\
\hline 7 & Cacabean & Ludwogoa Octovalvis & Mexican primsrose- \\
& & & willow \\
\hline 8 & Genjoran & Digitaria sanguinalis & Scop \\
\hline 9 & Jajagoan & Echinochloa crusgalli & Cockspur \\
\hline 10 & Grintingan & Paspalum distichum & Knotgrass \\
\hline
\end{tabular}


In Table 1, it can be seen that there is a type of mrana called lanas. The term in Kawi is also known by the Balinese peasant community called lanasan, with the characteristics of brown or red rice stalks. In modern agricultural science, this disease refers to rotten stem caused by the fungus Sclerotium oryzae (Defitri, 2017).

From no. 8, we can see there is a type of pest called Mati Busung. Mati Busung, when viewed from the meaning of the word, does not refer to a type of pest, but rather on the impact on rice caused by it. Based on the results of interviews with informants, Mati busung is a condition in which the new shoots of rice leaves suddenly wilt and die. In modern science, this condition is known as stem borers.

It is not specifically stated in the scripture of Usada Wisada Pari what kind of pest causes stem borers. However, according modern agricultural science, the most common types of stem borer are caused by 3 species, namely; 1 ) yellow rice stem borer (Scirpophaga incertulas), 2) white stem borer (S. innotata), and 3) striped stem borer (Manueke, Assa, \& Pelealu, 2018). This type of pest in Indonesian is often generalized as a moth. Stem borer pests are quite dangerous because they can attack rice plants, starting from seedbed to harvesting. The symptoms are shoots wilt, dry up and eventually die, and often followed by white panicles.

\section{Idenfitication of Tamba (Cure)}

The term Tamba, I closely related to the cure or the countermeasure of Mrana as the cause of agricultural pests. The scripture of Usada Wisada Pari contains several lexicons which can be categorized as Tamba.

From table 3, it can be concluded that the countermeasure is derived from plants and tools and means of ceremony. Several plants are not that well known until its synonym in Latin are found. These plants cover; 1) dhon tmen (caricature leaves), 2) don ambengan (reeds), 3) dhapdhap tmen (coral tree leaves), 4) don samida (samida leaves). Specific for samida leaves, it does not refer to a single type of leaf, rather it belongs to trees which spread a fragrant smell, which Hindus usually use to make incense. The word samida itself seems to be an uptake from the Sanskrit which means firewood. Furthermore, the translation from the scripture of Usada Wisada Pari also explains that samida leaves are those used for making fragrant smoke. Compared to traditional Balinese socio-cultural life, the types of fragrant trees for ceremonial facilities are usually between Sandalwood and Majegau (Dysoxylum densiflorum). Tamba (cure) from plants also functions as means of the ceremony as well as natural enemies of mrana. However, this group of plants is an uncommon means of yadnya ceremonies performed by Hindus, so it needs special emphasis since it only applies to handling epidemics in the perspective of this text.

Table 3 Lexicons of Tamba (Countermeasure)

\begin{tabular}{cll}
\hline No & \multicolumn{1}{c}{ Kawian } & \multicolumn{1}{c}{ English } \\
\hline 1 & $\begin{array}{l}\text { Yeh mawadah } \\
\text { payuk anyar }\end{array}$ & Pouring water into a new pot \\
\hline 2 & $\begin{array}{l}\text { Samsam dhon } \\
\text { tmĕn }\end{array}$ & Slices of caricature leaves \\
\hline 3 & Don ambengan & Reeds \\
\hline 4 & Baywan sorohan & Bayuan sorohan (a type of offerings) \\
\hline 5 & Tirtha & Holy Water \\
\hline 6 & Uyah aji keteng & Salt worth for one coin \\
\hline 7 & Bras kunning & Yellow rice \\
\hline 8 & Daksina & $\begin{array}{l}\text { Daksina (a means of offerings in the form of a basket consisting of } \\
\text { coconut, egg, rice, coins, and many others) }\end{array}$ \\
\hline 9 & Jinah 225 & Coins (worth for 225 pieces) \\
\hline 10 & Don samida & Samida Leaves \\
\hline
\end{tabular}




\begin{tabular}{lll}
\hline 11 & $\begin{array}{l}\text { Ampel gading } \\
\text { rinajah }\end{array}$ & Yellow shoot of bamboo \\
\hline 12 & Pcel ayam & One piece of chicken \\
\hline & $\begin{array}{l}\text { Twak } \\
\text { sinaringan, }\end{array}$ & Unfiltered palm wine \\
\hline 13 & Bubuh nasi & Porridge \\
\hline 14 & $\begin{array}{l}\text { Pamor nyunyuk } \\
\text { Crushed whiting with water }\end{array}$ & A tip of coral tree leaves \\
\hline 15 & $\begin{array}{l}\text { Muñcuk } \\
\text { dhapdhap, }\end{array}$ & Tricolor thread (red, white, black) \\
\hline 16 & Benang tridatu & Fire made from dry coconut fibers in cross shape $(+)$ \\
\hline 17 & Tkĕp api & Husk ash \\
\hline 18 & $\begin{array}{l}\text { Awon tabunan } \\
\text { Nasi takilan, } \\
\text { iwak taluh siap }\end{array}$ & Wrapped rice with eggs \\
\hline
\end{tabular}

\section{Reconstruction of Agricultural Outbreak Management according to Usada Wisada Pari}

There are various schemes of handling agricultural outbreaks according to the Usada Wisada Pari depending on the type of mrana (pest) that attacks the field. Usada Wisada Pari text explains about how to deal with other pests based on the specifications of the pests. However, the description of the scheme of handling agricultural outbreaks is not systematic (random). For example, the rat pest management is described in sections $1 \mathrm{~b}-2 \mathrm{a}$. After explaining on how to handle other types of pests in other sections, it turns out that in sections $4 \mathrm{~b}-5 \mathrm{a}$ the discussion of rat pests appears again. Therefore, in the following discussion, the review of scripture of Usada Wisada Pari will be specified according to the types of pests as follows.

Rats

The countermeasure for rat pests is the most described aspect in this scripture. Specifically, the most essential elements are found in sections $1 \mathrm{~b}-2 \mathrm{a}$. The description is provided as the following:

Mwang babanteñia baywan sorohan, raris katirtahin, baywane, wus mangkanä, ayabin baywan katurre, pada pisana, ma, ih iba bikul putih, luh mwani, tka tandhuh, iba bikul kuning, luh mwani, tka tandhuh, iba bikul barak, luh mwani, tka tandhuh, iba bikul irĕng, luh mwani, tka tandhuh, undhur rakna, iba bikul putih luh mwani, mulih kita ka gdhong putih, enakna kita poma (3), iba bikul barak, muluh mwani, mulih kita klod, ka gdhong tamagane, tka enak, poma (3) iba bikul slĕm, luh mwani, mulih kita kadya, ka gdhong bsi, poma (3), tka maluaran, ruwang idane kabeh.

Translation: The offering is bayuan sorohan, then it is sprinkled with holy water and some spell that utters," O you white mouse, male and female, come together, you yellow mouse, male and female, come together you rats. Red, male and female, come together. You black mouse, male and female, come together. Step back you male and female white rats, go back to your white hole, (pronounced 3 times), you male and female yellow rats, go back to the west, to the golden hole, please (pronounced 3 times), you male and female red rats, you will return to the south, to the copper barn, please (pronounced 3 times), you male and female black rats, come back to the north, to the iron barn, please (pronounced 3 times), come together, with all your friends.

Next, in section of $4 \mathrm{~b}-5 \mathrm{a}$, it describes various alternative ways to prevent rats from the rice field: Iti sasuwuk tikus, mwang tumbal tikus, śa, ampel gading, rinajah kaya iki, rajahnia pĕndhĕm, ring dalaning banyu, carunia, pcĕl ayam, twak tan sinaringan, malih hana, śa, bubuh nasi, iwaknia pamor nyunyuk, ma, Om sang hyang naga namban ana pari, ri sawah panunggun pa ri, ri sawah, sang hyang kuwuk, sarase, 
sirasuk onkon sira ri sawah, anunggu pari nira batara guru, sihi kedĕp mandhi mantranku, mwang sabdhanku.

Translation: These are the guards from rats, they cover yellow shoot of bamboo, which are chopped and buried where the water runs. For its offering, we need chicken, palm wine that is not filtered, as well as rice porridge with other materials such as crushed whiting poured with little bit of water and chant "Om sang hyang naga namban ana pari, ri sawah panunggun pa ri, ri sawah, sang hyang kuwuk, sarase, sirasuk onkon sira ri sawah, anunggu pari nira batara guru, sihi kedĕp mandhi mantranku, mwang sabdhanku".

\section{Stinker and Stem Borers}

Stinkers are one of the factors that causes rice production to decline. Stinker is a fruit-destroying pest that causes fruit to become empty (Tiwari, Prasad, \& Nath, 2011). When it is ripe, it also attacks rice grain and sucks the liquid in the rice fruit, causing the rice to have no grain (Fakhrur Rozi, Febrianti, \& Telaumbanua, 2018). Meanwhile, edema or stem borers are pests that only attack rice plantations. Symptoms of borer attack, in general, is in the vegetative phase called dead hearts with symptoms of dead young plants growing points. Symptoms of borer attack in the generative phase of whiteheads are symptomatic of dead panicles with hollow spikes that appear to be white (Baehaki, 2015).

The pests of stink bugs and edema (stem borer) are described in the statements in sections $2 b, 3 a$, $3 \mathrm{~b}, 4 \mathrm{a}$, and $5 \mathrm{a}$ that:

... ta balang sangit mwang tikus, mranā, mati busung, caddhangan, śa, uyah aji keteng, hdha nawah, ma, Om ulĕr brahmā, ulĕr wigrahā, haywa mangan parin ingșun, uyahhe sambĕhin ring sawah, ping 3.

Translation: ... furthermore, the countermeasure for stink bugs, rats, oedema, can be prevented by using salt that worth for one piece of coin, do not bargain, and chant: "Om ulĕr brahmāa, ulĕr wigrahā, haywa mangan parin ingșun", then sprinkle it on the rice fields three times.

Iki panyimpĕnang balang sangit, ma, mulih, kaja kangin, kalumpunia beru, balang ngapus malih klod kangin, kalumpunia dadu, i balang ngapi, mulih klod kawuh, kalumpunia tangi, I balang sasab, kalih kaja kawuh, kalumpunia gaddhang, eling ngakna gnahnia, poma, (3). Iki ngitgĕs pawedahan hyang śiwa gni, śa, tirta mantraknā, antuk hyang śiwa gni, mawasta kita pangundhurran balung, ma, ih balang sangit, mundhur kita, kaja kangin, lah mundhur, 3, iba balang ngawus, mundhurra kita klod kangin, tka mundhur, 3, Iba balang sangit, mundhur kita klod kawuh, tka mundhur, (3), Ih kita ki balang sasab, mundhur kita kaja kawuh, tka mundhur.

Translation: These are the chants to overcome stinkers: mulih, kaja kangin, kalumpunia beru, balang ngapus malih klod kangin, kalumpunia dadu, i balang ngapi, mulih klod kawuh, kalumpunia tangi, I balang sasab, kalih kaja kawuh, kalumpunia gaddhang, eling ngakna gnahnia, poma, (poma is pronounced 3 times).These are the manifestation of Sang Hyang SIwa Gni with holy water as a means to pray to him as well chant: ih balang sangit, mundhur kita, kaja kangin, lah mundhur, (mundhur diucap 3 kali), iba balang ngawus, mundhurra kita klod kangin, tka mundhur, (pronounced 3 times), ), Iba balang sangit, mundhur kita klod kawuh, tka mundhur, (pronounced 3 times), Ih kita ki balang sasab, mundhur kita kaja kawuh, tka mundhur".

Ta, balang sangit, śa, yeh ĕntip, wadahhin payuk anyar, muñcuk dhapdhap, 3, mucuk, matali bnang tridatu, mwang tkĕp api isinin awon tabunan, ma, muncrat muter ri bumi, mas ratna mutĕr ri jagat, $i$ warahi ni sarini bemo, sirat takna idĕr kiwa, ping, 3, sidi mandhi mantranku.

Translation: Furthermore, as a countermeasure for stinkers, we need water from rice crust, put it into a new pot with three leaves of coral tree in it, tied it with tricolor thread, and fire made from coconut fibers, the spell is: ; "muncrat muter ri bumi, mas ratna mutĕr ri jagat, i warahi ni sarini bemo", splash it around starting from the left three times and pray for the spell works.

Lanas (Rotten Stem) 
Lanas or known as rotten stem is outlined in the section of $2 b$ and $5 b-6 b$ as follows: ... punah lanas, śa, bras kunning, mwang dakșinā, 1, bras akulak, jinah, 225, ma, Om nini lanas, kaki lanas, yan a brahmmā sirĕp kita, yania lanas baluluk, lĕbur kita, yan ulĕr kuning, ngalilu kita, yan ulĕr irĕng pikpikitā, yan kita ulĕr lidah, ki siyah kita, mokșah akah kumangka kumingki, tka punah, (3).

Translation: To prevent rotten stem we need yellow rice and daksina (a kind of offering), a pack of rice, money worth 225 coins, and spell: "Om nini lanas, kaki lanas, yan a brahmmā sirĕp kita, yania lanas baluluk, lĕbur kita, yan ulĕr kuning, ngalilu kita, yan ulĕr irĕng pikpikitā, yan kita ulĕr lidah, ki siyah kita, mokșah akah kumangka kumingki, tka punah ("punah" is pronounced 3 times)."

ta pari lanasșan, śa, yeh anyar, awor tri katukā, dokna ring pangalapan, ma, Om salanas aranta, duk sira ring sabrang mlayu, tka ko kita, ring jawa bali, sila gumunta aranta, yen ana kala paurip sira nambĕ dening glap, Urip kang lanas, yan than ana kala pawurip silimbar dening glap, nora Urip kang lanas, mahandhadi sira mirĕng maha dadi mati busung, apannaku hanak i batara guru, hana munin șira, mundhura sira klod kawuh, pawundhurranta, sia 3, sirat akna idĕ kiwa, ping 3.

Translation: To prevent rice plants from rotten stem we need several elements including clean water combined with 3 spicy materials and do that before harvesting with spell: "Om salanas aranta, duk sira ring sabrang mlayu, tka ko kita, ring jawa bali, sila gumunta aranta, yen ana kala paurip sira nambe dening glap, urip kang lanas, yan than ana kala pawurip silimbar dening glap, nora urip kang lanas, mahandhadi sira mirĕng maha dadi mati busung, apannaku hana i batara guru, hanamunin șira, mundhura sira klod kawuh, pawundhurranta, sia" (pronounced three times), splash it around starting from the left three times.

Birds

The bird referred to in this context is a grain-eating bird. The birds that most often attack rice plants are the sparrows or kdis perit in Balinese. Until recently, sparrows are still considered a difficult pest to overcome because of their large population when attacking rice fields (Agust, Aminudin, \& Setiawan, 2019). Birds as one cause of the outbreaks are highlighted in a section of 3a as follows:

Puniki mamungkam kedis, śarana, daun samida, siratang, idĕr kiwa, mantra, Om kaki bungkam, nini bungkam, bungkam bah pang sangsang manuk, apangan parin i batara guru, pari mĕka palalianmu, tka bungkam...

Translation: This is to prevent birds with various means covering samida leaves (fragrant leaves used for incense), spreaded around starting from the left with spell: "Om kaki bungkam, nini bungkam, bungkam bah pang sangsang manuk, apangan parin i batara guru, pari mĕka palalianmu, tka bungkam."

Weeds

In order to handle weeds, it is explained in the section of $4 \mathrm{a}-4 \mathrm{~b}$ as follows:

Iti pangiyid jukutan, di sawahhe, ma, wuh kaki, tulaku mihid kita pundhukan, sinya idĕ ngkal pangkabahan sa hyang naga pasah, wastu tka iya katitip, ya nama swahā.

Translation: We do have spells to eradicate weeds from rice fields as follows; "wuh kaki, tulaku mihid kita pundhukan, sinya idĕngkal pangkabahan șa hyang naga pasah, wastu tka iya katitip, ya nama swah"̈.

\section{Monkey}

The countermeasure for monkey is stated in the section $5 \mathrm{~b}$ as follow:

Lih yan kamaranan, ring bojog, di sawahhe, śa, nasi takilan, iwak taluh siap 1, raris dhitu mangrādanā, di sawahhe, sabdhania dewa ratu, si rama druwe gumine driki, puniki titiang ngaturang gajaran, śa, awon siratang idĕr kiwa, pi, 3. 
Translation: There are more threats of pests in rice fields such as monkeys, to prevent it we must prepare wrapped rice with 1 egg in it, continued by rituals with saying; "dewa ratu, si rama druwe gumine driki, puniki titiang ngaturang gajaran", we also need husk ash sprinkled from the western part of the rice field and did it three times.

\section{Crows}

The explanation regarding how crows disturb agriculture can be found in the section $6 \mathrm{a}-6 \mathrm{~b}$ as follows:

Yan kamaranin gowak, śa, cannang atanding, mraka nyanyah gagrisingan, ma, Ih brabu itěm, brabu rawah dhabahdhabahang gowak, mangamah atandhuran batara guru, ampu brabu itĕm, brabu warah tatandhurra nirane, pomā, (3).

Translation: When the interference of crows exposes the field, prepare a means of offering in form of canang atanding containing raka nyanyah gagrisingan and spells: Ih brabu itĕm, brabu rawah dhabahdhabahang gowak, mangamah atandhuran batara guru, ampu brabu itěm, brabu warah tatandhurra nirane, pomā, (pronounced 3 times).

For other types of pests

The explanation of handling other kinds of pests which applies in general can be found in section 4a as follows:

Ta, salwirring mrana di sawahhe, śa, katutug, 5, mucuk tacěbang bilang bucu, pada sanunggal, ma, Om bapa akaśa, antari sabrang malayu, tka kita ring jawa bali, angaton nira walang sangit, i balang batu, I balang katumbah, caddhang lanas, mrĕngan, blukan, tongkilatan, mati busung, cicindhil, pada klod kawuh, paundhuran śira, ka tgal sawwang, tka pupug punah, (3), tka kedĕp śidi mandhi mantranku.

Translation: In order to handle all kinds of pests in rice fields, we need to prepare several means such as five stakes where they are tucked into the ground on each corner with spell: "Om bapa akaśa, antari sabrang malayu, tka kita ring jawa bali, angaton nira walang sangit, i balang batu, I balang katumbah, caddhang lanas, mrěngan, blukan, tongkilatan, mati busung, cicindhil, pada klod kawuh, paundhuran śira, ka tgal sawwang, tka pupug punah, (pronounced 3 times) tka kedĕp śidi mandhi mantranku".

From these quotations, it can be stated that the spell to overcome rats' problems is practically still pronounced in the Kawian (ancient Javanese) language. However, the translation must focus on several terms used as a sign. For instance, there are terms in handling rats like white, yellow, red, and black rats, where in fact it does not refer to the actual color of a rats, but it needs further interpretation.

In the description of Hinduism, the colors represent the cardinal directions. That is, the colors of the rats are intended to indicate that plague possibly comes from the four cardinal directions. This concept is indeed typical Shivaistic teaching connected to the cosmic balance and stability of the universe theory or identically called the concept of Panca Datu (five metal elements with different colors according to the direction of the wind give rise to the five strengths of life). The five elements are:

1. Iron with the chemical formula Fe, symbolizes the power of Lord Vishnu, is black in color, and occupies a position towards the North.

2. Silver with the chemical formula $\mathrm{Ag}$, symbolizes the power of Iswara, is white in color, and occupies a position in the East.

3. Copper with its chemical formula $\mathrm{Cu}$, symbolizing the power of Lord Brahma, is red in color, occupies a position towards the South.

4. Gold with its chemical formula Au, symbolizing the power of God Mahadeva, yellow in color, occupies a position towards the West. 
5. Brass with its chemical element CuZn, symbolizes the power of Lord Shiva, multicolor, occupies a position towards the Middle, as the axis or center of the universe (Jayendra, Sudarmawan, \& Wijaya, 2019, p. 137).

Based on this concept, it can be ascertained that this positive concept works as the cause of stability in accordance to the concept of rwabhineda (positive-negative elements) and works as the concept of negative forces simultaneously so that it becomes an epidemic. The white rat represents negative forces coming from the East, yellow from the West, red from the South, and black from the North.

The combination of the four elements of negative forces creates a plague in the Middle or axis and causes damage. In the Middle direction, as stated in the concept of Panca Datu resides Lord Shiva (Ida Sang Hyang Siwa Gni) as the god of fusion and destruction. Therefore, the effort made to overcome the rat pests was to hope Him melt and return the rats by breaking down the negative power and returning it to its original element. These are indicated in the utterance produced in the spell, some to mention are:

1. "... go back you white male and female rats, go back to your white hole..."

2. "... You yellow male and female rats, go to the west, to your golden hole"

3. "... You red rats, male and female, go to your south, to your copper hole"

4. "... You black male and female rats, go to your north, to the iron hole"

It can be clearly stated that the ceremony is carried out aimed at deciphering the elements of negative forces that cause the rat plague, melting them and returning them to their origin, and turning the elements of negative forces into positive ones. From the observations, these procedures and concepts are not widely known by the farming community because the community has not yet popularized the essence of knowledge regarding the handling of rat plague, according to the scripture of Wisada Pari. Most people still adhere to the Nangluk Merana ceremony. However, suppose you look at the attitudes and behavior of the Balinese people who actually respect the plague of rats by honouring it with title "Jero Ketut". In that case, it is very relevant to the contents of the Usada Wisada Pari text which describes the origin rats that come from power and direction of the gods according to Shivaistic teachings. Meanwhile, the practice described in sections $4 \mathrm{~b}-5 \mathrm{a}$ has not been found to date.

An identical pattern is also found in the spell of handling stinkers. The translation of the spell can be presented as follows:

"o stinkers, go back you to the northeast, go back now (3 times).

"You grasshopper, go back you to the south-east, go back now (3 times)

"You stink bugs, go back you to the north-west, go back now (3 times)

"you locust, go back you to the south-west, go back now.

Viewing from the direction of origin of the disease, it is clear that this is also part of the practice of Shivaistic teachings. Focusing on the cardinal directions from where the rats come will create a complete constellation of cardinal directions (8 directions) with one centrum. In relation to the concept of Dewata Nawa Sangha, the eight cardinal directions have one more: the center with Lord Shiva as the centrum. In the Shivaistic concept, the combination of the 9 cardinal directions has 10 sacred characters, namely $\mathrm{Sa}, \mathrm{Ba}, \mathrm{Ta}, \mathrm{A}, \mathrm{I}, \mathrm{Na}, \mathrm{Ma}, \mathrm{Si}, \mathrm{Wa}, \mathrm{Ya}$ (center has two characters, I and $\mathrm{Ya}$ ). Thus, it is necessary to mention that Lord Shiva personified as Ida Sang Hyang Siwa Gni is tasked with dissolving and returning the entire plague back to its origin. In addition, positive energy stability will be created in all constellations of the cardinal directions that have implications for the stability of life. This is symbolized by the flourishing of the seeds of life, which is the rice plant itself.

The same interpretation also refers to handling all types of pests (point 8), where there is a quote from the sentence "antari sabrang malayu, tka kita ring jawa bali". Literally, the meaning can be interpreted as "coming from across the Malay, coming and arriving in Java - Bali". On the other hand, the interpretation given based on the informant's data is more to the language code which contains a more Shivaistic philosophical meaning. The word "malayu" is interpreted coming from the word "malaya" in the sense of referring to the Himalayas, the name of the highest mountain in the world. Mountain in Sanskrit is called "lingacala", derived from the words "linga" and "acala" which means a motionless. 
The Lingga itself in the Hindu concept, is a symbol of Lord Siva. The word "Java" here refers to the term "jaba" in ancient Javanese, meaning outer or sekala, while "bali" comes from the word "wali" which means sacred or. This actually implies a message that to prevent all kinds of diseases, the farmers are always taught to worship Lord Shiva and running agriculture is not only limited to physical effort but also carries out religious and sacred aspects. Thus, it is clear that in the scripture of Usada Wisada Pari, Lord Shiva is the main personification worshipped in relation to the prevention and overcoming of the agricultural outbreak. Lord Shiva in his duties as the god destruction, in this case, has duties to atone for all kinds of plague for the sake of creating a successful, abundant rice harvest.

\section{Conclusion}

The scripture of Usada Wisada Pari is one of the texts in Bali that describes agriculture, especially in handling outbreaks or pests. The Usada Wisada Pari is a noble cultural heritage that should be preserved. The understanding of the contents of this text also enriches the socio-cultural knowledge of the Balinese Hindu community.

The Usada Wisada Pari is an ancient Javanese text, generally describing the plague that often harms farmers, ranging from rats, stink bugs, wild grasses and wild monkeys that disturb rice plants in rice fields. This text contains the identification of lexicons, namely mrana and tamba. Mrana is a term that refers to a pest or the source of the plague, while tamba refers to scheme to handle or eradicate agricultural plague.

The reconstruction of the scheme of handling agricultural plague according to the Usada Wisada Pari varies depending on the type of mrana (pest) that occurs, such as rats, stink bugs and stem borer, rotten stem, birds, weeds, monkeys, crows, and other pests. Even though the handling is different, the scripture of Usada Wisada Pari implies that all diseases and their treatment are centered on the authority of Lord Shiva as the god of fusion. Therefore, to prevent pest attacks, farmers are expected to carry out agricultural activities from a physical perspective and sacred and religious ceremonial aspects since it is a determining factor in the harvest's success.

The application of the results of this research is expected to have implications for the patterns of agricultural pest management carried out by the community. The synergy of religious, environmental, and socio-cultural aspects makes it important to be adapted into a unified ethnoagriculture. Thus, this study also contributes positively to the development of modern agricultural patterns that promote more environmentally friendly ways.

\section{References}

Agust, T. R., Aminudin, A., \& Setiawan, A. (2019). Sistem cerdas pengusik burung pipit sebagai hama padi menggunakan passive infrared dan pembangkit ultrasonik. Seminar Nasional Fisika, 1(1), 429-435.

Ardana, I. K. (2012). Sekala Niskala: Realitas Kehidupan Dalam Dimensi Rwa Bhineda. Dewa Ruci: Jurnal Pengkajian Dan Penciptaan Seni, 8(1), 139-156.

Ardiyasa, I. N. S. (2020). Mitigasi Spritual dalam Naskah Lontar Roga Sanghara Bhumi. Sanjizwani: Jurnal Filsafat, 10(1), 27-36. https://doi.org/10.25078/sjf.v10i1.1629

Artayasa, I. W. (2017). Pemujaan Terhadap Bhatari Sri Sebagai Dewi Kemakmuran Dalam Lontar Dharman Pamacul. Prosiding Seminar Nasional Bahasa Dan Budaya. Denpasar: Institut Hindu Dharma Negeri Denpasar.

Baehaki, S. E. (2015). Hama penggerek batang padi dan teknologi pengendalian. Iptek Tanaman Pangan, 8(1).

Defitri, Y. (2017). Identifikasi Jamur Patogen Penyebab Penyakit pada Tanaman Padi (Oryza Sativa) di Lubuk Ruso Kecamatan Pemayung Kabupatenbatanghari Jambi. Jurnal Ilmiah Universitas Batanghari Jambi, 13(4), 113-117.

Diari, K. P. Y. (2020). Aspek Eko-Religius dalam Naskah Lontar Pertanian di Bali. Singaraja: Sekolah Tinggi Agama Hindu Negeri Mpu Kuturan.

Fakhrur Rozi, Z., Febrianti, Y., \& Telaumbanua, Y. (2018). Potensi Sari Pati Gadung (Dioscorea hispida L.) Sebagai Bioinsektisida Hama Walang Sangit Pada Tanaman Padi (Oryza sativa L.). Biogenesis: Jurnal Ilmiah Biologi, 6(1), 18-22. https://doi.org/10.24252/bio.v6i1.4185

Jayendra, P. S. (2021). Makna Simbolik Dewa Nini Sebagai Bentuk Sakralisasi Budaya Agrikultur Masyarakat Hindu Bali. OSF Preprints. https://doi.org/10.31219/osf.io/7wtes

Jayendra, P. S., Sudarmawan, I. W. E., \& Wijaya, N. S. (2019). Eksistensi Produk Pis Bolong Sebagai Media Edukasi Religiusitas Budaya Bali Bagi Wisatawan Di Desa Kamasan, Klungkung. Jurnal Ilmiah Hospitality 
Management, 9(2), 134-145. https://doi.org/10.22334/jihm.v9i2.153

Ladja, F. T., Hidayat, S. H., Damayanti, T. A., \& Rauf, A. (2016). Deteksi Virus Tungro pada Gulma Padi Sawah Menggunakan Teknik PCR. Jurnal Penelitian Pertanian Tanaman Pangan, 35(1), 39-44. https://doi.org/10.21082/jpptp.v35n1.2016.p39-44

Manueke, J., Assa, B. H., \& Pelealu, E. A. (2018). Hama-Hama Pada Tanaman Padi Sawah (Oryza Sativa L.) Di Kelurahan Makalonsow Kecamatan Tondano Timur Kabupaten Minahasa. EUGENIA, 23(3), $120-127$. https://doi.org/10.35791/eug.23.3.2017.18964

Ogburn, W. F. (1922). Social Change With Respect to Culture and Original Nature. New York: Huebsch.

Rukmana, H. R., \& Saputra., U. U. (1999). Gulma dan Teknik Pengendalian. Yogyakarta: Kanisius.

Sartini, N. W. (2017). Makna simbolik bahasa ritual pertanian masyarakat Bali. Jurnal Kajian Bali (Journal of Bali Studies), 7(2), 99-120.

Tiwari, G. N., Prasad, C. S., \& Nath, L. (2011). Arthropod Diversity in Brinjal Ecosystem and its Relation with Weather Factors in Western Uttar Pradesh. Trends in Biosciences, 4(1), 12-18.

Yuantari, M. G. C. (2011). Dampak pestisida organoklorin terhadap kesehatan manusia dan lingkungan serta penanggulangannya. Prosiding Seminar Nasional Peran Kesehatan Masyarakat Dalam Pencapaian MDG's Di Indonesia, 187-199.

(C) 2021 by the authors. Submitted for possible open access publication under the terms and conditions of the Creative Commons Attribution (CC BY SA) license (https://creativecommons.org/licenses/by-sa/3.0/). 
This page is intentionally left blank 